\title{
Analisis Jual Beli Paket Data Internet dalam Perspektif Ekonomi Islam Di Kecamatan Rasanae Barat Kota Bima
}

\author{
Umar Sagaf ${ }^{1^{*}}$, Suci Surianah ${ }^{2}$ \\ 1,2) Institut Agama Islam Muhammadiyah Bima \\ *Corresponding Author: umarsagaf72@gmail.com
}

\begin{abstract}
ABSTRAK - Penelitian ini bertujuan untuk mengetahui Jual Beli Paket Data Internet Menurut Perspektif Ekonomi Islam. Untuk mencapai tujuan tersebut maka peneliti menggunakan metode penelitian kualitatif dalam penelitian bersifat deskriptif yang mengarah pada fakta-fakta yang terjadi mengenai jual beli paket data internet dengan menggunakan pengumpulan data seperti wawancara, observasi, dan dokumentasi. Dan yang menjadi tempat penelitian disini adalah di Konter Apunk Cell, Konter Market Cell, dan Konter Royal Cell yang ada di Kecamatan Rasanae Barat Kota Bima. Setelah dilakukan penelitian maka di dapat kesimpulan bahwa (1) Jadi hukum jual beli kartu paket data internet ditinjau dari perspektif Sayyid Sabiq sebenarnya diperbolehkan, hanya saja Sayyid Sabiq mengatakan bahwa jual beli ini boleh terjadi ketika para pihak, penjual dan pembeli mengetahui keadaannya baik mencakup kuantitas dan kualitasnya, dikarenakan jual beli ini terdapat unsur ketidakjelasan dan ketidakpastian barang sehingga konsumen atau pembeli banyak yang dirugikan oleh tingkah pelaku usaha, maka dari itu jual beli ini dilarang sebagaimana dilihat dari pendapat Sayyid Sabiq, ia mengatakan jika hanya satu orang yang mengetahuinya maka jual belinya batal dan tidak sah karena terdapat unsur ketidakpastian dan ketidakjelasan (gharar).
\end{abstract}

Kata Kunci - Jual beli; paket data internet; ekonomi Islam.

\begin{abstract}
This study aims to determine the sale and purchase of internet data packages according to the perspective of Islamic economic. To achieve this goal, the researcher uses qualitative research methods in descriptive research that leads to facts that occur regarding buying and selling internet data packages using data collection such as interviews, observations, and documentation. And the research sites here are the Apunk Cell counters, Market Cell counters, and Royal Cell counters in Rasanae Barat subdistrict, Bima city. After doing research, it can be councluded that, (1) So the law of buying and selling internet data package cards in terms of the perspective of Sayyid Sabiq is actually allowed, it's just that Sayyid Sabiq said that this sale and purchase may occur when the parties, the seller and the buyer know the situation is good including the quantity and quality, due to this sale and purchase. There is an element of ambiguity and uncertainty of goods so that many consumers or buyers are harmed by the behavior of business actors, therefore is prohibited as seen from the opinion of Sayyid Sabiq, he said that if only one person knew about it then the sale and purchase was null and void because there were elements uncertainty and ambiguity (gharar).
\end{abstract}

Keywords - Buying and selling; internet data packages; Islamic economy.

\section{PENDAHULUAN}

Muamalah adalah bagian dari hukum Islam yang mengatur hubungan antara dua pihak atau lebih dalam suatu transaksi. Dari pengertian ini ada dua hal yang menjadi ruang lingkup dari muamalah. Pertama, bagaimana transaksi 
itu dilakukan. Hal ini menyangkut dengan etika (adabiyah) suatu transaksi, seperti ijab kabul, saling meridhai, tidak ada keterpaksaan dari salah satu pihak, adanya hak dan kewajiban masing-masing, kejujuran atau mungkin ada penipuan, pemalsuan, penimbunan, dan segala sesuatu yang bersumber dari indra manusia yang ada kaitannya dengan peredaran harta dalam kehidupan masyarakat. Kedua, apa bentuk transaksi itu. Ini menyangkut materi (madiyah) transaksi yang dilakukan, seperti jual beli, pegang gadai, jaminan dan tanggungan, pemindahan utang, perseroan harta dan jasa, sewa menyewa dan lain sebagainya. ${ }^{1}$

Berbicara tentang Jual Beli, Jual beli (al-bai) secara etimologi atau bahasa adalah pertukaran barang dengan barang (barter). Sedangkan Jual beli (al-bay) secara terminologi yaitu tukar menukar harta benda atau sesuatu yang diinginkan dengan sesuatu yang sepadan melalui cara tertentu yang bermanfaat. $^{2}$

Semua perintah dalam ajaran Islam pasti dimaksudkan untuk kemaslahatan hidup, sebaliknya semua larangan pasti mengakibatkan kemudharatan dalam tatanan hidup. Demikian pula dalam jual beli, adapun hukum yang memperbolehkan jual beli ini terdapat dalam Q.S Al-Baqarah ayat $275: 3$

Terjemahan: "...Padahal Allah telah menghalalkan jual beli dan mengharamkan riba..."

Berdasarkan terjemahan ayat tersebut dapat diambil pemahaman bahwa Allah SWT Telah menghalalkan jual beli kepada hamba-hambanya dengan baik dan melarang praktek jual beli yang mengandung riba. Adapun sahnya jual beli tersebut apabila terpenuhinya rukun dan syarat, diantaranya adalah wujud dari obyek transaksi dapat diketahui dengan jelas, dapat diserahkan dan dapat dihargakan. Begitu pula dalam akad jual beli yang harus dilakukan berdasarkan keinginannya sendiri tanpa adanya unsur keterpaksaan dari siapa pun.

Kebutuhan masyarakat terhadap telekomunikasi didukung oleh kecanggihan teknologi informasi sangatlah berpengaruh dalam kehidupan sehari-hari. Perkembangan telekomunikasi juga tidak hanya berkembang pada aspek telekomunikasi saja, seperti pengguna aplikasi perusahaan jasa star up terbaru. Jadi, untuk dapat terhubung ke internet melalui penggunaan telekomunikasi tersebut harus menggunakan alat-alat komunikasi seperti Laptop, Tablet, atau Smartphone yang bisa menghubungkan ke jaringan

1Dudi Badruzaman. Prinsip-Prinsip Muamalah Dan Inplementasinya Dalam Hukum Perbankan Indonesia. Maro, Jurnal Ekonomi Syariah dan Bisnis, Vol. 1. No. 2, E-ISSN: 2621-5012. November 2018. 110

2Syaifullah M.S. Etika Jual Beli Dalam Islam. Hunafa: Jurnal Studia Islamika, Vol. 11, No. 2, Desember 2014: 371-387. 373.

${ }^{3}$ QS. Al-Baqarah (2): 275. 
internet, dikarenakan banyaknya pengguna alat komunikasi tersebut tak luput dari penggunaan kuota internet.

Oleh karena itu, kartu paket data internet kini sudah menjadi sebuah kebutuhan bagi masyarakat, bagi siapapun baik orang dewasa, remaja, bahkan anak-anak sekalipun, jika ingin mengakses informasi terkait apa saja dengan mudah dan cepat. Berkomunikasi dengan orang lain pun sudah mudah melalui media sosial, sehingga membuat hidup menjadi lebih praktis, semua itu dapat dilakukan melalui alat komunikasi masa kini dengan adanya kartu paket data internet. ${ }^{4}$

Berdasarkan hasil survey awal yang dilakukan si peneliti dengan 3 konter yang menjual paket data internet yang ada di Kecamatan Rasanae Barat Kota Bima. Peneliti menemukan beberapa masalah terkait transasksi jual beli paket data internet ini, pertama masih ada para penjual paket data internet yang ketika melakukan jual beli paket data internet tidak menjelaskan secara detail tentang seputar paket data internet baik dari seberapa banyaknya kuota internet yang tersedia dalam setiap kartu paket data internet maupun seberapa lamanya masa aktif kuota internet tersebut ketika mulai digunakan, ini ditandai dengan ketika saat terjadinya transaksi antara penjual dan pembeli, penjual langsung menyerahkan barang berupa kartu paket data internet kemudian pembeli menyerahkan uang sebagai alat pembayaran tanpa adanya interaksi lebih lama. Kedua, ada juga penjual paket data internet ketika saat melakukan transaksi pelayanan berlangsung, dimana ketika penjual melayani pembeli tidak bersikap ramah. ${ }^{5}$ Ketiga berdasarkan hasil wawancara dengan salah seorang pembeli si peneliti juga menemukan bahwa, ketika si pembeli melakukan registrasi pada kartu paket data yang telah dibeli, kuota internet yang masuk tidak sesuai dengan yang tertera pada foster. Berangkat dari latar belakang di atas, maka saya sebagai penulis tertarik untuk melakukan penelitian dengan judul "Analisis Jual Beli Paket Data Internet Dalam Perspektif Ekonomi Islam Di Kecamatan Rasanae Barat Kota Bima".

\section{LANDASAN TEORI}

\section{Tinjauan Umum Jual Beli}

\section{Pengertian Jual Beli}

Menurut bahasa, jual beli berarti menukarkan sesuatu dengan sesuatu. ${ }^{6}$ Sedangkan menurut istilah yang dimaksud jual beli atau bisnis adalah:

\footnotetext{
4Hendrawan, "Wawancara”, Bima 17 Februari 2021.

5Observasi awal, Kecamatan Rasanae Barat Kota Bima, 17 Februari dan 15 Maret 2021.

6Shobirin. Jual Beli Dalam Pandangan Islam. Jurnal Bisnis dan Manajemen Islam, BISNIS Vol. 3 No. 2, Desember 2015. 241.
} 
1. Menukar barang dengan barang atau barang dengan uang dengan jalan melepaskan hak milik dari yang satu kepada yang lain atas dasar saling merelakan.

2. Menurut Syekh Muhammad ibn Qasim al-Ghazzi: Menurut syara', pengertian jual beli yang paling tepat ialah memiliki sesuatu harta (uang) dengan mengganti sesuatu atas dasar izin syara', sekedar memiliki manfaatnya saja yang diperbolehkan syara' untuk selamanya yang demikian itu harus dengan melalui pembayaran yang berupa uang.

3. Menurut Imam Taqiyuddin dalam kitab Kiffayatul al-Akhyar: Saling tukar harta, saling menerima, dapat dikelola (tasharruf) dengan ijab qobul dengan cara yang sesuai dengan syara'.

4. Syeikh Zakaria al Anshari dalam kitabnya fath Al-Wahab: Tukar-menukar benda lain dengan cara yang khusus (dibolehkan).

5. Menurut Sayyid Sabiq dalam Kitabnya Fiqh Sunnah: Penukaran benda dengan benda lain dengan jalan saling atau memindahkan hak milik dengan ada penggantinya dengan cara yang diperbolehkan.

6. Ada sebagian ulama memberikan pemaknaan tentang jual beli (bisnis), diantaranya; Ulama Hanafiyah "Jual beli adalah pertukaran harta dengan harta (benda) berdasarkan cara khusus (yang di bolehkan) syara' yang disepakati”. Menurut Imam Nawawi dalam al-majmu' mengatakan “Jual beli adalah pertukaran harta dengan harta untuk kepemilikan". Menukar barang dengan barang atau barang dengan uang dengan jalan melepaskan hak milik atas dasar saling merelakan. ${ }^{7}$

\section{Dasar hukum jual beli}

1. Al-Qur'an dan Hadits

Dasar hukum jual beli dalam al-Qur'an sebagaimana disebutkan dalam surat al-Baqarah ayat 275:

Terjemahan: "...Padahal Allah telah menghalalkan jual beli dan mengharamkan riba..."

Allah SWT mengharamkan kepada umat Islam memakan harta sesama dengan jalan batil, misalnya dengan cara mencuri, korupsi, menipu, merampok, memeras, dan dengan jalan lain yang tidak dibenarkan Allah, kecuali dengan jalan perniagaan atau jual beli dengan didasari atas dasar suka sama suka dan saling menguntungkan. ${ }^{8}$ Nabi SAW bersabda dalam hadis yang diriwayatkan oleh Imam Bazzar. Dari Rif'ah Ibn Rafi

7Wati Susiawati, Jual Beli Dan Dalam Konteks Kekinian. Jurnal Ekonomi Islam Volume 8, Nomor 2, November 2017. 172-173.

8 Wati Susiawati. Jual Beli Dan Dalam Konteks Kekinian. 174. 
sesungguhnya Rasulullah SAW pernah ditanya: " usaha apa yang paling baik? Rasulullah SAW menjawab "Usaha seseorang dengan tangannya sendiri dan setiap jual beli yang mabrur (jujur)". (H.R. Al-Al-Bazzar dan disahihkan oleh alHakim).

Berdasarkan hadist diatas bahwa jual beli hukumnya mubah atau boleh, namun jual beli menurut Imam Asy Syatibi hukum jual beli bisa menjadi wajib dan bisa haram seperti ketika terjadi ihtikar yaitu penimbunan barang sehingga persedian dan harga melonjak naik. Apabila terjadi praktek semacam ini maka pemerintah boleh memaksa para pedagang menjual barang sesuai dengan harga dipasaran dan para pedagang wajib memenuhi ketentuan pemerintah didalam menentukan harga dipasaran serta pedangan juga dapat dikenakan saksi karena tindakan tersebut dapat merusak atau mengacaukan ekonomi rakyat. ${ }^{9}$

2. Ijma'

Ulama telah sepakat bahwa jual beli diperbolehkan dengan alasan bahwa manusia tidak akan mampu mencukupi kebutuhan dirinya, tanpa bantuan orang lain. Namun demikian, bantuan atau barang milik orang lain yang dibutuhkannya itu, harus diganti dengan barang lainnya yang sesuai dengan kesepakatan antara penjual dengan pembeli atau dengan alat tukar menukar yaitu dengan uang ataupun yang lainnya. ${ }^{10}$

\section{Rukun dan Syarat Jual Beli}

Adapun syarat, menurut terminologi para fuqaha seperti diformulasikan Muhammad Khudlari Bek, ialah sesuatu yang ketidak adanya mengharuskan (mengakibatkan) tidak adanya hukum itu sendiri. ${ }^{11}$ Rukun-rukun dan syaarat jual beli diantaranya:

1. Penjual dan pembeli

Syaratnya adalah:

a. Berakal, agar dia tidak terkecoh. Orang yang gila atau bodoh tidak sah jual belinya.

b. Dengan kehendak sendiri (bukan dipaksa). Keterangannya yaitu ayat dari surah Q.s An-nisa:29

c. Tidak mubazir (pemboros), sebab harta orang yang mubazir itu ditangan walinya.

d. Balig (berumur 15 tahun keatas/dewasa). ${ }^{12}$

9Shobirin. Jual Beli Dalam Pandangan Islam. 244.

10 Ibid..., 244.

11Wati Susiawati. Jual Beli Dan Dalam Konteks Kekinian.........., 175.

${ }^{12}$ H. Sulaiman Rasjid. Figh Islam (Hukum Figh Islam), Cetakan 65. (Bandung: Sinar Baru Algensindo, 2013), 279.

J-ESA (Jurnal Ekonomi Syariah) 
2. Uang dan benda yang dibeli Syaratnya adalah:

a. Suci.

b. Ada manfaatnya.

c. Barang itu dapat diserahkan.

d. Barang tersebut merupakan kepunyaan si penjual, kepunyaan yang diwakilinya, atau yang mengusahakan.

e. Barang tersebut diketahui oleh si penjual dan pembeli, zat, bentuk, kadar (ukuran), dan sifat-sifatnya jelas, sehingga antara keduanya tidak akan terjadi kecoh-mengecoh. ${ }^{13}$

3. Lafaz Ijab dan Kabul

Ijab adalah kata-kata yang keluar dari penjual seperti. "Aku menjual”. Kabul adalah kata-kata yang keluar daari pembeli seperti. "Aku membeli". Ini adalah Shighat yang bersifat perbuatan, maka ia adalah tindakan saling memberikan, yaitu; memberi dan menerima, misalnya pembeli memberikan harga barang kepada penjual, lalu menyerah barang tanpa ucapan (diantara keduanya). ${ }^{14}$ Adapun syarat-syarat barang yang diperjualbelikan menurut Sayid Sabiq yaitu:

a. Bersih barangnya

b. Dapat dimanfaatkan

c. Milik orang yang melakukan akad/milik sendiri

d. Mampu menyerahkan

e. Diketahui barangnya dengan jelas dan,

f. Barang yang diakadkan ada di tangan.

Menurut jumhur ulama menyatakan bahwa rukun jual beli ada empat, yaitu:

a. Ada orang yang melakukan akad atau al-muta'aqidain (peenjual dan pembeli)

b. Ada sighat (lafal ijab dan kabul)

c. Ada barang yang dibeli

d. Ada nilai tukar pengganti barang.

\section{Prinsip Dasar Jual Beli Menurut Islam}

1. Prinsip pertama: Hukum asal setiap perniagaan adalah halal

2. Prinsip kedua: Memudahkan orang lain.

3. Prinsip ketiga: Kejelasan status

4. Prinsip keempat: Tidak merugikan masyarakat banyak

${ }^{13}$ H. Sulaiman Rasjid. Fiqh Islam (Hukum Figh Islam ).........., 280- 281.

${ }^{14}$ Abdul Aziz Mabruk AL-Ahmadi dkk. Fikih Muyassar........., 346. 
5. Prinsip kelima: Kejujuran

6. Prinsip keenam: Niat seseorang mempengaruhi hukum transaksi

7. Prinsip ketujuh: Peran adat istiadat dalam perniagaan.

\section{Jual Beli yang Dilarang dalam Islam}

1. Jual beli yang dilarang karena Gharar dan Jahalah

2. Macam-macam jual beli yang diharamkan karena Gharar dan Jahalal15

3. Jual beli yang dilarang karena Riba

4. Jual beli yang dilarang karena memudaratkan dan mengandung penipuan. ${ }^{16}$

\section{Jual Beli dalam Perspektif Muhammad Sayyid Sabiq}

\section{Pengertian Jual Beli}

Sayyid Sabiq dalam kitab fiqih sunnah menerangkan jual beli secara etimologi bahwa jual beli menurut pengertian lughawiyah adalah saling menukar (pertukaran). Kata bai' (jual) dan syira' (beli) digunakan biasanya dalam pengertian yang sama. Dan kata ini masing-masing mempunyai makna dua, yang satu dengan yang lainnya bertolak belakang. ${ }^{17}$ Sedangkan menurut istilah, jual beli dalam padangan Sayyid Sabiq dalam buku fikih sunnah yang dimaksud dengan jual beli (bai) secara syariat adalah pertukaran harta dengan harta dengan saling meridhoi, atau pemindahan kepemilikan dengan penukaran dalam bentuk yang diinzinkan. ${ }^{18}$

\section{Dasar Hukum Jual Beli}

Adapun yang menjadi dasar landasan hukum disyariatkannya jual beli adalah sebagai berikut:

1. Landasan Al-Qur'an
a. Surah al-baqarah (2) ayat 275:
b. Surah al-baqarah (2) ayat 282:
c. Surat an-Nisa (4) ayat 29:

2. Landasan as-Sunnah

Hadits Rifa'ah Ibnu Rafi

Terjemahannya: Dari ibnu Rafi bahwa Nabi ditanya uasaha apakah yang paling baik? Nabi menjawab: usaha seseorang dengan tangannya sendiri dan setiap jual beli yang mabrur.

Dari ayat-ayat Al-qur'an dan hadits-hadits yang dikemukakan diatas dapat dipahami bahwa jual beli merupakan pekerjaan yang halal dan mulia. Apabila pelakunya jujur, maka kedudukan diakhirat nanti setara dengan para Nabi syuhada, shiddiqin.

15 Ibid..., 105-114

16 Ibid..., 127-145

17 http:/ / digilib.uinsby.ac.id

18 http://eprints.walisongo.ac.id 


\section{Rukun Dan Syarat Jual Beli}

Menurut Sayyid Sabiq syarat dan rukun jual beli terdiri dari:

1. Sighat (pernyataan)

2. Aqidayn (yang membuat perjanjian),

Adapun syarat-syaratnya:

a. Aqil (berakal). Karena hanya orang yang sadar dan berakallah yang sanggup melakukan transaksi jual beli secara sempurna.

b. Tamyiz (dapat membedakan). Sebagai pertanda kesadaran untuk membedakan yang baik dan buruk.

c. Mukhtar (bebas atau berkuasa memilih), yaitu bebas melakukan transaksi jual beli, lepas dari paksaan dan tekanan, berdasarkan dari dalil al-Qur'an surah an-Nisa ayat 29.

3. Ma'qud 'alaih, yaitu barang yang dijual belikan.

Syaratnya yaitu:
a. Suci
b. Bermanfaat
c. Milik penjual
d. Bisa diserahkan, dan
e. Diketahuai keadannya.

4. Ada nilai tukar pengganti barang (harga barang). ${ }^{19}$

\section{Macam-Macam Jual Beli}

1. Jual beli Gharar

Sayyid Sabiq mengartikan gharar sebagai berikut: ${ }^{20}$

Terjemahannya: "Gharar adalah penipuan yang mana dengannya diperkirakan mengakibatkan tidak adanya kerelaan jika diteliti".

2. Gharar dalam benda yang berlaku pada aqadnya

a. Ketidakpastian pada dzat benda yang ditransaksi

b. Ketidakjelasan pada jenis barang yang ditransaksikan

c. Ketidakjelasan pada macam barang yang ditransaksi

d. Ketidakjelasan pada sifat benda yang ditransaksikan

e. Ketidakjelasan pada kabar benda yang ditransaksikan

f. Ketidakjelasan pada tempo penentuan harga

g. Tidak adanya kemampuan menyerahkan benda yang ditransaksikan

h. Transaksi pada benda yang tidak ada

i. Tidak bisa melihat benda yang ditransaksikan 21

${ }_{19}$ Muhammad idris harap. Hukum jual beli paket kuota internet berdasarkan perspektif sayyid sabiq (studi kasus di jalan imam bonjol kelurahan kisaran timur kabupaten asaha). ("skripsi" UIN Sumatera utara). 2017 M. 25

20 Ibid...28

${ }^{21}$ Ibid... 34-37. 


\section{Tinjauan Umum Paket Internet}

\section{Pengertian Paket Internet}

Paket internet adalah sebuah layanan yang disediakan oleh operator telekomunikasi atau data dimana konsumen diharuskan untuk membayar sejumlah nominal rupiah sebagai biaya pemakaian internet atau data. Bagi pengguna telpon seluler bila tidak menggunakan paket internet, maka setiap kali melakukan koneksi data atau internet, biaya diambil dari pulsa telepon. ${ }^{22}$

\section{Kualitas Jaringan Internet}

Menurut Waode, kualitas jaringan adalah suatu titik yang menghubungkan antara satu titik dengan titik lainnya dengan adanya koneksi yang tersedia sehingga dapat melakukan komunikasi antar orang lain untuk menyampaikan suatu informasi. ${ }^{23}$ Tiga parameter yang dapat menentukan QoS pada jaringan antara lain; Throughput, Packet loss, Delay, dan Jitter. ${ }^{24}$

\section{Pembuatan Kode Program}

Pembuatan kode program ini meghasilkan pemesanan paket kuota untuk memudahkan pelanggan dalam pelayanan. Berikut penjelasan tiap-tiap bagian dalam pengembangan sistem ini; petugas admin dan pelanggan. ${ }^{25}$

\section{Tinjauan Umum Internet}

\section{Pengertian Internet}

Pengertian internet menurut para ahli:

1. Lani Sidharta, mengatakan internet adalah suatu interkoneksi sebuah jaringan komputer yang dapat memberikan pelayanan informasi secara lengkap.

2. Khoe Yao Tung mengatakan internet adalah jaringan yang satelit komunikasi yang fungsinya sangat beragam dan tentu merupakan pendukung internet diseuluruh dunia.

\section{Dampak Positif dan Negatif dalam Manfaat Internet}

Berbagai dampak positif dalam pemanfaatan internet beserta penjelasanya menurut Supriyanto sebagai berikut:

1. Internet sebagai media komunikasi

2. Media pertukaran data

22 Fitriyani Dan Ellya Helmud. Pemilihan Paket Internet Android Pada Operator Telepon GSM Menggunakan Metode Analytical Herarchy Process (AHP). Jurnal Sistem Informasi (JSI), Vol 8, No.1, April 2016. 921.

${ }^{23}$ Aprillia Bunga Cindy. Analisis Pengaruh Harga Paket, Kualitas Jaringan Dan Promosi Terhadap Keputusan Pembelian Kartu Perdana Internet (Survei Mahasiswa Fakultas Dan Ekonomi Dan Bisnis Unervesitas Muhammadiyah Surakarta). (“Skripsi” UMS, Surakrta 2017). 3.

24 Nur Azizah Dkk. "Analisis Quality Of Service Jaringan Internet PT. Jawa Pos National Network Medialink Pontianak". Dalam https://media.neliti.com, diambil tanggal 9 Mei 2021, pukul 11.11 Wita.

${ }^{25}$ Setia Ilmi dkk. “Aplikasi Pemesanan Paket Kuota Internet Pada Gudang Kuota Lampung Tengah Berbasis Web". Dalam http:/ / eprints.jeb.polinela.ac.id diambil pada tanggal 9 mei 2021, pukul 11:35 Wita. 
3. Media untuk mencari informasi atau data

4. Kemudahan dalam memperoleh informasi

5. Sumber informasi

6. Kemudahan berbisnis

7. Sumber penghasilan

Sementara itu, dampak negatif dalam pemanfaatan internet menurut Supriyanto adalah pornografi, Violence and gore, penipuan, dan Carding.

\section{Fungsi Internet}

Kenzi kitao mengatakan ada enam fungsi internet yang dapat dimanfaatkan dalam kehidupan sehari-hari yaitu: Alat komunikasi, akses informasi, pendidikan dan pembelajaran, berfungsi sebagai suplemen tambahan, fungsi pelengkap internet sebagai komplemen atau pelengkap, dan fungsi pengganti.

\section{METODOLOGI PENELITIAN}

\section{Jenis Penelitian}

Jenis penelitian ini menggunakan jenis penelitian kualitatif karena penelitian ini tidak menggunakan alat uji statistik untuk memperoleh data. Dalam penelitian ini si peneliti juga perlu menekankan pada pentingnya kedekatan dengan orang-orang dan situasi penelitian, agar peneliti memperoleh pemahaman yang jelas tentang realitas dan kondisi kehidupan nyata. Sifat penelitian yang dilakukan oleh peneliti yaitu bersifat deskriptif. Penelitian deskriptif dalam bentuk kualitatif dalam proposal ini adalah penelitian yang mengarah pada fakta-fakta yang terjadi mengenai jual beli paket data internet dalam perspektif ekonomi Islam (studi kasus di Kecamatan Rasanae Barat Kota Bima).

\section{Sumber Data dan Jenis Penelitian}

1. Sumber data

Dari penelitian ini si peneliti mendapatkan data dari sumber data primer. Untuk menjawab pertanyaan penelitian, dalam penelitian ini peneliti memperoleh sumber data primer dari bapak Hendrawan, ibu Rosmiati, ibu Imah selaku penjual paket data internet dan pembeli paket data internet di Kecamatan Rasanae Barat Kota Bima.

2. Jenis data

Untuk jenis data dalam penelitian ini adalah menggunakan jenis data primer berdasarkan cara memperolehnya dengan memperoleh data langsung dari lapangan, yaitu data yang dikumpulkan oleh si peneliti melalui 3 penjual paket data internet (konter Royal Cell, konter Market Cell dan konter Apunk Cell) berupa hasil penjualan paket data internet pada 
tahun 2021 dan pembeli paket data internet dengan mendatangi langsung konter para penjual paket data internet.

\section{Teknik Pengumpulan Data}

Teknik pengumpulan data yang digunakan adalah dokumentasi, wawancara, dan observasi.

\section{Teknik Analisis Data}

Metode ini penulis gunakan untuk menggambarkan dan menganalisis hukum Islam tentang jual beli paket data internet yang terjadi di Kecamatan Rasanae Barat Kota Bima adalah reduksi data, penyajian data, dan menarik kesimpulan atau verifikasi.

\section{HASIL PENELITAN DAN PEMBAHASAN \\ Penyajian Data}

Data yang diperoleh penliti, baik yang dapat melalui observasi, wawancara, maupun dokumentasi harus dapat disajikan. Adapun beberapa cara penyajian data sebagai berikut:

1. Wawancara

Adapun pertanyaan-pertanyaan yang diajukan terhadap penjual diantaranya:

a. Kartu paket data dan Voucher apa sajakah yang dijual?

Berdasarkan wawancara peneliti dengan ibu Rosmiati selaku penjual dikonter Apunk Cell, bahwa:

“Disini kami menjual paket data internet hanya 2 saja yaitu dari Telkomsel dan XL berlaku juga dengan vouchernya. Alasan kami hanya menjual 2 kartu paket data saja karena sejak kami membuka usaha ini untuk kartu paket data dari Axis tidak terlalu banyak peminatnya". ${ }^{26}$

Berdasarkan wawancara peneliti dengan bapak Hendrawan selaku pemilik dan penjual paket data internet di konter Market Cell, bahwa:

"Seperti yang anda lihat, bahwa saya disini menjual paket data dari Telkomsel, Axis dan XL begitu juga dengan vouchernya" ${ }^{27}$

Berdasarkan wawancara dengan ibu Imah selaku penjual dikonter Royal Cell, bahwa:

“Untuk dari konter kami hampir sama dengan apa yang dijual oleh konter lain, kami pun juga menjual paket data internet dari XL, Telkomsel dan Axis, untuk vouchernya juga sama ada yang dari Axis, Telkomsel dan XL". 28

${ }^{26}$ Rosmiati Kariawan Konter Apunk Cell, “Wawancara” Bima, 22 Juli 2021.

27 Hendarawan Pemilik Konter Market Cell “Wawancara” Bima, 29 Juli 2021.

28 Imah Kariawan Konter Royal Cell “Wawancara” Bima, 30 Juli 2021 
b. Apa yang membedakan antara menggunakan Kartu paket dan menggunakan Voucher?

Berdasarkan wawancara peneliti dengan ibu Rosmiati, bahwa:

"Untuk keduanya lebih hemat menggunakan kartu paket ketimbang menggunakan voucher, karena disaat kuota internet sudah habis untuk selanjutnya kita bisa isi pulsa sendiri lalu bisa daftar paket internet dengan pilihan diskon kuota yang tersedia, sedangkan voucher dia sekali pakai saja dalam jangka waktu tertentu. Cara menggunakannya, untuk kartu paket data mengharuskan pembeli untuk meregristrasi kartu sebelum mengktifkan data sedangkan voucher itu cukup mentransfer kuota ke kartu paket data sebelumnya" ${ }^{29}$

Berdasarkan wawancara peneliti dengan bapak Hendrawan, bahwa:

"Kartu paket data dan voucher itu sama, yang dimana voucher itu adalah kuota internet yang sudah di injek terlebih dahulu oleh perusahaan dan cara menggunakannya dengan mentranfer kuota internet ke kartu paket data sebelumnya melauli kode voucher, namun yang membedakannya voucher lebih murah dari kartu paket data. Karena ketika kita menggunakan kartu maka kuota internet sesuai dengan yang tercantum pada foster, sedangkan pada voucher ada pengurangan jumlah kuota" ${ }^{30}$

Berdasarkan wawancara dengan ibu Imah, bahwa:

"Kartu paket data itu diregristrasi dulu sebelum digunakan sedangkan voucher itu langsung ditransfer ke kuota sebelumnya yang suda dipakai, untuk harga voucher memang sedikit berbeda dengan kartu paket data internet karena memang pada voucher ada pengurangan jumlah kuota, jadi ketika menggunakan voucher dia lebih murah harganya". ${ }^{31}$

c. Bagaimana penetapan harga jual dari kartu paket data internet?

Berdasarkan wawancara peneliti dengan ibu Rosmiati, bahwa:

"Penetapan harga jual paket data internet itu ditentukan oleh pihak konter sendiri namun dilihat dari harga jual dari pihak lain, ini juga dilihat dari modal yang dikeluarkan. Setiap kartu paket data keuntungan yang diperoleh tidak dipungut terlalu besar" ${ }^{32}$

Berdasarkan wawancara peneliti bersama bapak Hendrawan, bahwa:

\footnotetext{
${ }^{29}$ Rosmiati Kariawan Konter Apunk Cell “Wawancara” Bima, 22 Juli 2021

30 Hendrawan Pemilik Konter Market Cell “Wawancara” Bima, 29 Juli 2021.

31 Imah Kariawan Konter Royal Cell “Wawancara” Bima, 30 Juli 2021

32 Rosmiati Kariawan Konter Apunk Cell “Wawancara” Bima, 22 Juli 2021
} 
"Untuk penetapan harga jual itu ditentukan sendiri oleh saya sebagai penjual, namun tidak terlepas melihat dari harga pasar atau penepatan harga jual dari pihak lain. ${ }^{33}$

Berdasarkan wawancara peneliti dengan ibu Imah, bahwa:

"Penetapan harga jual tidak ditentukan oleh perusahaan namun ditentukan sendiri oleh pihak konter, ini dilihat juga dari harga jual dari penjual lainnya". ${ }^{34}$

d. Apakah anda sebagai penjual menjelaskan terlebih dahulu terkait kartu paket data internet kepada si pembeli?

Berdasarkan wawancara peneliti dengan ibu Rosmiati, bahwa:

“Untuk penjelasan paket data internet kepada pembeli itu tergantung pembeli yang menanyakannya baru saya akan menjelaskan terkait paket data internet. Adapun penjelasan-penjelasan yang saya jelaskan hanya pada paket data ini berlaku selama 1 bulan dan harga setiap kartu paket data internet". 35

Berdasarkan wawancara peneliti dengan bapak Hendrawan, bahwa:

"Setiap pembeli itu berbeda-beda ada yang sudah mengetahui cara menggunakan paket data internet dan ada juga yang sama sekali tidak tahu cara menggunakan paket data internet. Saya sebagai penjual akan menjelaskan apabila ada diantara pembeli yang mulai menanyakan paket data internet, terkadang saya juga langsung menjelaskannya sebelum pembeli yang menanyakannya" ${ }^{36}$

Berdasarkan wawancara peneliti dengan ibu Imah, bahwa:

“Terkait penjelasan paket data internet, saya tidak terlalu menjelaskannya kepada pembeli karena pembeli jarang menanyakan terakait paket data internet, namun saya akan menjelaskan setelah pembeli mulai menanyakannya". ${ }^{37}$

Adapun pertanyaan-pertanyaan yang peneliti ajukan pada saat wawancara dengan pembeli paket data internet, diantaranya:

a. Bagaimana tanggapan ibu/bapak tentang pelayanan yang dilakukan oleh si penjual paket data internet di konter ini?

Berdasarkan hasil wawancara peneliti dengan mba Riska selaku pembeli paket data internet, bahwa:

"Saat saya membeli paket data internet pelayanan yang diberikan cukup memuaskan salah satu contohnya jika saya meminta mereka

\footnotetext{
${ }^{33}$ Hendrawan Pemilik Konter Maket Cell “Wawancara” Bima, 29 Juli 2021

34 Imah Kariawan Konter Royal Cell “Wawancara” Bima, 30 Juli 2021

35 Rosmiati Kariawan Konter Apunk Cell “Wawancara” Bima, 22 Juli 2021

36 Hendrawan Pemilik Konter Maket Cell “Wawancara” Bima, 29 Juli 2021

37 Imah Kariawan Konter Royal Cell “Wawancara” Bima, 30 Juli 2021
} 
menjelaskan cara meregistrasi kartu paket data internet beliau langsung menjelaskannya". ${ }^{38}$

Berdasarkan hasil wawancara peneliti dengan mba Nuraini, bahwa:

"Selama saya membeli paket data internet pelayanan yang diberikan cukup bagus mulai dari perilaku yang ramah, sopan, tidak pernah kasar dan hal tersebut menurut saya cukup menjamin bahwa pelayanan yang diberikan sangat baik". ${ }^{39}$

b. Pada saat ibu membeli paket data internet, adakah dari pihak penjual menjelaskan terlebih dahulu tentang paket data internet?

Berdasarkan wawancara peneliti dengan mba Riska, bahwa:

“Tidak ada penjelasan secara detail dari pihak penjual, adapun yang mereka jelaskan hanya pada pilihan kartu paket data internet dan kuotanya saja" ${ }^{40}$

Berdasarkan wawancara dengan mba Nuraini, bahwa:

“Untuk penjelasannya tidak ada kak, mereka sebagai penjual hanya sekedar menunjukan berbagai jenis kartu paket data internet saja". ${ }^{41}$

c. Setelah kartu paket data internet di registrasi, apakah kuota yang ada kartu paket data internet sudah sesuai dengan yang tertera dalam foster?

Berdasarkan wawancara dengan mba Riskwa, bahwa:

"Untuk hal demikian, saya pernah mengalaminya. Setelah saya registrasi kartu paket data internet, kuota internet yang masuk itu tidak sesuai yang tertera pada fosternya, saat itu saya membeli paket data internet dari Telkomsel yang $5 \mathrm{~Gb}$ dan yang masuk tidak sampai $5 \mathrm{~Gb}$, dan hal tersebut pernah saya alami sebanyak 2 kali". ${ }^{42}$

Berdasarkan wawancara dengan mba Nuraini, bahwa:

"Alhamdulillah, selama saya menggunakan kartu paket data internet kuota internet selalu sesuai dengan yang tertera pada foster" ${ }^{43}$

2. Observasi

Adapun temuan hasil observasi dalam penelitian ini sebagai berikut:

a. Perilaku penjual terhadap pembeli baik dalam pelayanan maupun penyampaian terkait kartu paket data internet:

Berdasarkan hasil observasi peneliti pada konter Apunk Cell, menunjukan bahwa:

“Ketika pembeli mendatangi konter Apunk Cell, pihak penjual tidak menyapa pembeli terlebih dahulu seperti mengucapkan salam kepada

\footnotetext{
38 Riska Pembeli “Wawancara” Bima, 23 April 2021.

39 Nuraini Pembeli “Wawancara” Bima, 23 April 2021.

40 Riska Pembeli “Wawancara” Bima, 23 April 2021.

${ }^{41}$ Nuraini Pembeli “Wawancara” Bima, 23 April 2021.

42 Riska Pembeli “Wawancara” Bima, 23 April 2021.

43 Nuraini Pembeli “Wawancara” Bima, 23 April 2021.
} 
pembeli begitu juga sikap dari pihak pembeli, bahkan ucapan selamat pagi atau siang pun tidak ada dari pihak penjual, senyum yang ditunjukan oleh penjual terkadang ada dan tidak. Perlayanan yang diberikan oleh Apunk Cell terhadap penyampaian paket data internet juga tidak ada, jika memang ada itu tergantung pembeli yang mulai menanyakan tentang paket data.Ini dilihat dari interaksi dari penjual dan pembeli yang tidak terlalu lama". ${ }^{4}$

Sedikit berbeda dengan konter Market Cell, hasil observasi peneliti dikonter Market Cell juga menunjukan bahwa"

"Pelayanan yang diberikan oleh penjual terhadap pembeli hampir sama, pihak penjual tekadang mengucapkan salam dan terkadang juga tidak, dan hal pertama yang ditanyakan oleh pihak penjual yaitu "ada yang bisa kami bantu?" sebagai pemula pertemuan, setelah ada respon dari pembeli yang ingin membeli paket data, maka pihak penjual akan mengijinkan pembeli untuk melihat-lihat dulu paket data apa yang diinginkan. Berkaitan dengan penjelasan paket data internet, penjual dari konter Market Cell akan mulai menjelaskan apabila pembeli mulai menanyakannya, terkadang beliau juga akan langsung menjelaskannya". ${ }^{45}$

Hal ini juga serupa yang ditunjukan oleh pihak penjual di konter Royal Cell, yang dimana berdasarkan hasil Observasi peneliti di konter Royal Cell menunjukan bahwa:

“Saat pembeli mendatangi konter, pihak pembeli akan langsung menanyakan kepada penjual apakah ada paket data yang dijual, setelah ada jawaban dari penjual maka pembeli dijinkan untuk melihat-lihat paket data yang diinginkan. Sikap yang ditujukan oleh pembeli tidak terlalu ramah seperti tidak ada sapaan salam dan senyum. Begitu juga penyampaian paket data internet tidak ada dari pihak penjual, penjual akan mulai menjelaskan terkait paket data apabila pembeli mulai menanyakannya". ${ }^{46}$

b. Kesesuaian akad dalam transaksi jual beli paket data internet:

Pada saat terjadinya transaksi jual beli paket data internet, akad yang digunakan di 3 konter tersebut adalah akad jual beli yang dimana didalamnya ada penjual dan pembeli.Ada barang (kartu paket data internet dan voucher) yang dibeli dan ada uang sebagai alat pembayara.Serta ada lafaz dan ijab qalbu, ini dilihat dari pernyataan penjual terhadap pembeli untuk menjual barangnya begitupun pernyataan dari pembeli untuk membeli barang tersebut (paket data internet).

${ }^{44}$ Observasi Konter Apunk Cell, Bima 22 Juli 2021 Pukul 09:30 Wita. 45Observasi Konter Market Cell, Bima 29 Juli 2021.Pukul 09:30 Wita. 46Observasi Konter Royal Cell, Bima 30 Juli 2021.Pukul 09:30 Wita. 
c. Komunikasi detail ke pembeli:

1) Tidak ada penjelasan jangka waktu paket data internet

2) Pembagian kuota

3) Cara meregistrasi kartu paket data dan cara mentranfer kuota

4) Penjelasan pengurangan jumlah kuota pada voucher

5) Perubahan pembagian kuota pada setiap penyeluaran kartu terbaru dari perusahaan, yang disampaikan oleh penjual terhadap pembeli.

3. Dokumentasi

Dokumentasi dalam penelitian ini untuk melengkapi data-data dan untuk memperkuat hasil penelitian. Dokumentasi ini dilakukan di 3 konter yang ada di Kecamatan Rasanae Barat Kota Bima yaitu di konter Apunk Cell, konter Market Cell dan konter Royal Cell, sebagai berikut:

a. Kartu paket data dan Vouchrer XL

\begin{tabular}{|c|l|c|c|}
\hline No. & Jenis & Isi & Harga \\
\hline 1. & Perdana Internet & $8 \mathrm{~GB}$ & 35.000 \\
\hline 2. & Perdana Internet & $13 \mathrm{~GB}$ & 45.000 \\
\hline 3. & Perdana Internet & $25 \mathrm{~GB}$ & 70.000 \\
\hline 4. & Perdana Internet & $44 \mathrm{~GB}$ & 105.000 \\
\hline 5. & Perdana Internet & $66 \mathrm{~GB}$ & 125.000 \\
\hline 6. & Voucher Internet & $6 \mathrm{~GB}$ & 35.000 \\
\hline 7. & Voucher Internet & $10 \mathrm{~GB}$ & 45.000 \\
\hline 8. & Voucher Internet & $23 \mathrm{~GB}$ & 70.000 \\
\hline 9. & Voucher Internet & $42 \mathrm{~GB}$ & 105.000 \\
\hline 10. & Voucher Internet & $64 \mathrm{~GB}$ & 125.000 \\
\hline
\end{tabular}

Sumber: Data konter Royal Cell, Juli 2021.

b. Kartu paket data dan Vouchrer Axis

\begin{tabular}{|c|c|c|c|}
\hline No. & Jenis & Isi & Harga \\
\hline 1. & Perdana Internet & $33 \mathrm{~GB}$ & 15.000 \\
\hline 2. & Voucher Internet & $3 \mathrm{~GB}$ & 20.000 \\
\hline 3. & Voucher Internet & $6 \mathrm{~GB}$ & 30.000 \\
\hline
\end{tabular}

Sumber: Data konter Royal Cell, Juli 2021.

c. Kartu paket data dan Vouchrer Simpati / AS

\begin{tabular}{|c|c|c|c|}
\hline No. & Jenis & Isi & Harga \\
\hline 1. & Perdana internet & $5 \mathrm{~GB}$ & 40.000 \\
\hline 2. & Voucher internet & $1,5 \mathrm{~GB}$ & 12.000 \\
\hline
\end{tabular}




\begin{tabular}{|c|c|c|c|}
\hline 3. & Voucher internet & $2,5 \mathrm{~GB}$ & 20.000 \\
\hline
\end{tabular}

Sumber: Data konter Royal Cell, Juli 2021.

\section{Analisis Data dan Pembahasan}

\section{Analisis Data}

1. Pelayanan yang diberikan dan penjelasan paket data internet.

Dapat dilihat bahwa cara pelaksanaan penjualan paket data internet di Konter tersebut, hanya sebatas memasang baner didepan konter untuk menjukan bahwa konter tersebut menjual jenis paket data yang terdiri dari paket data Telkomsel, Axis dan XL dengan harga yang tersedia dan besar kuotanya saja, yang dimana dalam hal ini tidak ada penjelasan yang lebih dari pihak-pihak penjual terhadap pembeli terkait paket data internet.

2. Proses akad jual beli paket data internet

Menurut Sayid sabiq ada beberapa yang perlu diperhatikan saat proses akad jual beli diantaranya: 47

a. Aqidayn (yang membuat perjanjian) adanya penjual dan pembeli.

b. Sighat (pernyataan), yaitu ijab dan qabul (serah terima).

c. Ma'qud 'alaih, yaitu barang yang dijual belikan.

d. Ada nilai tukar pengganti barang (harga barang)

3. Komunikasi detail ke Pembeli

Penjelasan barang jual beli paket data internet, tidak hanya sebatas pada penjelasan-penjelasan pada isi kuota, masa aktif dan harga jual. Tetapi dalam hal ini penjual juga perlu untuk menjelaskan seperti:

a. Pembagian kuota

b. Cara meregistrasi kartu paket data dan cara mentransfer kuota

c. Penjelasan pengurangan jumlah kuota pada voucher

d. Perubahan pembagian kuota pada setiap penyeluaran kartu terbaru dari perusahaan, yang disampaikan oleh penjual terhadap pembeli.

\section{Pembahasan}

1. Pandangan Ekonomi Islam Dalam Jual Beli Paket Data Internet di Kecamatan Rasanae Barat Kota Bima.

Dikalangan masyarakat sekarang juga timbul permasalahan yang perlu kita kaji ulang kembali, yaitu pelaksanaan praktek jual beli kartu paket kuota internet yang dilakukan di konter Apunk Cell, konter Market Cell dan Konter Royal Cell yang ada di Kecamatan Rasanae Barat Kota Bima, jika di tinjau dari perspektif Sayyid Sabiq jual beli ini tidak di perbolehkan/haram

${ }^{47}$ Muhammad idris harap. Hukum jual beli paket kuota internet berdasarkan perspektif sayyid sabiq (studi kasus di jalan imam bonjol kelurahan kisaran timur kabupaten asaha). ("skripsi" UIN Sumatera utara). 2017 M. 25

J-ESA (Jurnal Ekonomi Syariah) 
karena didalamnya mengandung unsur gharar. Sebagaimana Sayyid Sabiq mengartikan gharar sebagai berikut:

Terjemahan: "Gharar adalah penipuan yang mana dengannya diperkirakan mengakibatkan tidak adanya kerelaan jika diteliti".

Adapun gharar dalam benda disini yang dimaksud oleh Sayyid Sabiq diantaranya, ketidakpastian pada dzat benda yang ditransaksi dan ketidakjelasan pada jenis barang yang ditransaksikan. Jadi jual beli ini berdasarkan perpektif Sayyid Sabiq dan menurut analisis peneliti bahwa jual beli ini tidak diperbolehkan, karena jual beli ini boleh terjadi ketika para penjual dan pembeli mengetahui keadannya baik mencakup kuantitas dan kualitasnya, dan jika hanya satu orang yang mengetahuinya maka jual belinya batal dan tidak sah.

\section{KESIMPULAN}

Setelah melakukan penelitian terhadap analisis jual beli paket data internet menurut perspektif ekonomi Islam di Kecamatan Rasanae Barat Kota Bima, peneliti menyimpulkan bahwa hukum jual beli kartu paket kuota internet ditinjau dari perspektif Sayyid Sabiq sebenarnya diperbolehkan, hanya saja Sayyid Sabiq mengatakan bahwa jual beli ini boleh terjadi ketika para pihak, penjual dan pembeli mengetahui keadaanya baik mencakup kuantitas dan kualitasnya, dikarenakan jual beli ini terdapat unsur ketidakjelasan dan ketidakpastian barang sehingga konsumen atau pembeli banyak yang dirugikan oleh tingkah pelaku usaha, maka dari itu jual beli ini dilarang sebagaimana dilihat dari pendapat Sayyid Sabiq, ia mengatakan jika hanya satu orang yang mengetahuinya maka jual belinya batal dan tidak sah karena terdapat unsur ketidakpastian dan ketidakjelasan (gharar)

\section{DAFTAR PUSTAKA}

Abdul Aziz Mabruk AL-Ahmadi dkk. Fikih Muyassar Panduan Praktis Fikih Dan Hukum Islam. ISBN:978-979-1254-99-1. Cetakan D, Penerbit Darul Haq, Jakarta $1441 \mathrm{H} / 2008 \mathrm{M}$.

Abdul Munib. Hukum Islam Dan Muamalah (Asas-asas hukum Islam dalam bidang muamalah). Fakultas Agama Islam UIM Pamekasan, JURNAL PENELITIAN DAN PEMIKIRAN KEISLAMAN, ISSN. 2355-0104 EISSN. 2549-3833, Vol. 5. No.1, Februari 2018.

Ahmad Fijali. Analisis Data Kualitatif. Jurnal Alhadharah Vol.17 No.33 JanuariJuni 2018.

Ahmad Usamn. Mari Belajar Meneliti. ISBN:978-979-3988-32-0. Cetakan 1, Pencentak LENGGE PRINTIKA, Maret 2008. 
Aprillia Bunga Cindy. Analisis Pengaruh Harga Paket, Kualitas Jaringan Dan Promosi Terhadap Keputusan Pembelian Kartu Perdana Internet (Survei Mahasiswa Fakultas Dan Ekonomi Dan Bisnis Unervesitas Muhammadiyah Surakarta). (“Skripsi” UMS, Surakrta 2017).

Cnbcindonesia.com. Perusahaan Telekomunikasi

Dudi Badruzaman. Prinsip-Prinsip Muamalah Dan Inplementasinya Dalam Hukum Perbankan Indonesia. Maro, Jurnal Ekonomi Syariah dan Bisnis, Vol. 1. No. 2, E-ISSN: 2621-5012. November 2018.

Enang hidayat. Fikih Jual Beli. ISBN 978-979-692-568-1, Cetakan Pertama, Penerbit PT REMAJA ROSDAKARYA. Februauri 2015.

Fitriyani Dan Ellya Helmud. Pemilihan Paket Internet Android Pada Operator Telepon GSM Menggunakan Metode Analytical Herarchy Process (AHP). Jurnal Sistem Informasi (JSI), Vol 8, No.1, April 2016.

Hamni Fadlilah Nasution. Instrument Penelitian Dan Urgensinya Dalam Penelitian Kualitatif. Dalam http://jurnal.iain-padangsidimpuan.ac.id

Hayatun Nufus. Tinjauan Fikih Muamalah Terhadap Praktik Jual Beli Paket Data Internet (Studi Kasus Di Desa Kualu Nenas, Kelurahan Dusun IV SP Durian Kecamatan Tambang, Kabupaten Kampar). ("Skripsi" UIN SUSKA RIAU, Pekanbaru 2020).

H. Sulaiman Rasjid, Fiqh Islam (Hukum Fiqh Islam). ISBN 978-979-8482-28-1, Cetakan 65. Penerbit Sinar Baru Algensindo Bandung Anggota IKAPI no.025/IBA, Bandung 2013.

Kamus Besar Bahasa Indonesia.

Muhamad Arifin bin Badri. Panduan Praktis Fikih Perniagaan Islam Berbasis Dan Berdagang Sesuai Sunnah Nabi Saw. ISBN: 978-979-1254-97-7, Cetakan 1, Penerbit Darul Haq, Jakarta Rajab 1436 H/ Mei 3015 M.

Muhammad Yunus dkk. Tinjauan Fikih Muamalah Terhadap Akad Jual Beli Dalam Transaksi Online Pada Aplikasi Go-Food. Amwaluna: Jurnal Ekonomi dan Keuangan Syariah Vol. 2 No. 1, ISSN: 2540-8399, January 2018.

Nuning Indah Pratiwi, Penggunaan Media Video Call Dalam Teknologi Komunikasi. Jurnal Ilmiah Dinamika Sosial, Volume 1, Nomor 2, ISSN:2581-2424. Agustus 2017.

Nur Azizah Dkk. "Analisis Quality Of Service Jaringan Internet PT. Jawa Pos National Network Medialink Pontianak". Dalam https://media.neliti.com, Nur Chamid. Jejak Langkah Sejatah Pemikiran Ekonomi Islam. ISBN: 978-602-876475-9. Cetakan II, Penerbit PUSTAKA PELAJAR. Mei 2017. 
Purnama Lestari. Tinjauan Hukum Islam Tentang Jual Beli Dengan Sistem Taksir (Studi Pada Pasar Perumnas Way Halim Bandar Lampung). ("Skripsi", UIN RADEN INTAN, Lampung 1441 H / 2019 M).

Setia Ilmi dkk. "Aplikasi Pemesanan Paket Kuota Internet Pada Gudang Kuota Lampung Tengah Werbasis . Walam http://eprints.jeb.polinela.ac.id

Shobirin. Jual Beli Dalam Pandangan Islam. Jurnal Bisnis dan Manajemen Islam, BISNIS Vol. 3 No. 2, Desember 2015.

Sri Sudiarti. Fiqh Muamalah Kontemporer. ISBN: 978-602-6903-26-6. FEBI UINSU Press, Medan Oktober 2018.

Syaifullah. Etika Jual Beli Dalam Islam. Hunafa: Jurnal Studia Islamika, Vol. 11, No. 2, Desember 2014: 371-387.

Thalha Alhawid Dan Budur Anufia. Resume: Instrument Pengumpulan Data. Dalam http://osf.io

Vina Veriani dan Angky Febriasyah. Tinjauan Atas Proses Penyusunan Laporan Keuangan Pada Young Enterpreneur Academy Indonesia Bandung. Jurnal Riset Akutansi, Volume VIII/No.2/ISSN:2086-0447. Oktober 2016

Wati Susiawati. Jual Beli Dan Dalam Konteks Kekinian. Jurnal Ekonomi Islam Volume 8, Nomor 2, November 2017.

http://repository.upi.edu

http:// digilib.uinsby.ac.id.

http://repository.redenintan.ac.id

http://repository.ump.ac.id.

https://elib.unikom.ac.id. 